\title{
HIGH SCHOOL STUDENTS' ERROR IN SOLVING WORD PROBLEM OF TRIGONOMETRY BASED ON NEWMAN ERROR HIERARCHICAL MODEL
}

\author{
Thalitha Ariesti Widhia Wardhani*, Deshinta P.A.D. Argaswari \\ Sampoerna University, Indonesia
}

\begin{tabular}{l} 
Article Info \\
\hline Article history: \\
Received Jun 29, 2021 \\
Revised Dec 27, 2021 \\
Accepted Jan 10, 2022 \\
\hline
\end{tabular}

Keywords:

High School Students,

Newman Error,

Students' Error,

Trigonometry,

Word Problem

\begin{abstract}
This study aims to identify students' errors in solving word problems of trigonometry according to the Newman Error Hierarchical Model. This study uses qualitative descriptive data gathered based on fact, and data analysis presented descriptively. The population is students of X IPA 2 at SMAN 1 Cikarang Utara, West Java, Indonesia, and to understand more about the error that happened, the researcher took six students of SMAN 1 Cikarang Utara as a sample. The sample is chosen by purposive sampling. Instrument tests, interviews, and documentation are the data collected. This study used the Newman Error Hierarchical Model to analyze high school students' errors in solving word problems of trigonometry. The results show that students made errors in comprehension, transformation, process skill, and encoding stage. The errors were caused by their lack of understanding some words and terms in the word problem, lack of ability in transforming the word problem to the mathematical model and strategy, lack of processing the algebra and calculation, lack of motivation, and carelessness.
\end{abstract}

This is an open access article under the CC BY-SA license.

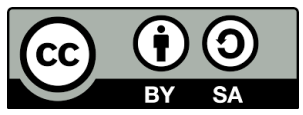

\section{Corresponding Author:}

Thalitha Ariesti Widhia Wardhani,

Mathematics Education Department,

Faculty of Education, Sampoerna University

Jln. Raya Pasar Minggu Kav. 16, Pancoran, South Jakarta, DKI Jakarta 12780, Indonesia

Email: ariestytalita@gmail.com

\section{How to Cite:}

Wardhani, T. A. W., \& Argaswari, D. P. A. D. (2022). High school students' error in solving word problem of trigonometry based on Newman error hierarchical model. Infinity, 11(1), 87-102.

\section{INTRODUCTION}

Trigonometry is one of the topics that high school students learn when studying mathematics. It is the study of integrating the relationship between sides and angles (Franklin, 2006). Furthermore, it covers the study of triangles, the relationships between their sides and angles, the functions of sine and cosine, tangent and cotangent, secant and cosecant (Walsh et al., 2017). Trigonometry is a critical topic in mathematics in order to prepare students for advanced mathematics, including calculus (Hidayat \& Aripin, 2020; Hidayat \& Riyana, 2021). Aside from its importance for advanced mathematics, trigonometry contributes to many applications in non-mathematical fields such as 
architecture, civil engineering, cartography, geophysics and other advanced fields (Galarza, 2017). Therefore, it is important for students to understand trigonometry well. However, students found it abstract and difficult compared to other mathematics subjects (Gur, 2009). It is because students have learning complexity in develop the understanding of subject matter content knowledge of trigonometry concept. Moreover, students have obstacles about trigonometry, especially when they are given word problems.

According to Dewanto et al. (2017), word problems are mathematics problems that provide opportunities for students to support them linking the relationship between mathematics and real-life context. It is not only depends on students' ability to perform the required mathematical operations, but also on the extent to which they are able to accurately understand the text of the word problem (Boonen et al., 2016). Students need to be able to solve word-problems because it is a crucial learning outcome and is considered an essential skill in mathematics (Cuevas, 2000). Moreover, word problem tasks can also be used to assess the level of comprehension to the mathematical concepts (Khoshaim, 2020). However, students consider solving word problems difficult (Fatmanissa \& Sagara, 2017; Haryanti et al., 2019; Said \& Tengah, 2021; Sanwidi, 2018). Moreover, it is shown that more than $50 \%$ of teachers in Indonesia complained about students' difficulties in solving word problem (Fatmanissa et al., 2020; Fatmanissa \& Sagara, 2017).

A trigonometry word problem is a mathematical word problem related to trigonometry. When solving the word problem of trigonometry, students require to possess both trigonometry understanding and word problem solving skill (Arhin \& Hokor, 2021; Hamzah et al., 2021; Mensah, 2017). For some cases, students also require doing multi-steps to solve the problem. Studies reported that solving a mathematical word problem with multisteps can create more error in obtaining the right answers (Dewanto et al., 2017). Moreover, the report of the National Examination result of High School of 2018 shows that there are only $33.05 \%$ of students in Indonesia, and $30.03 \%$ of students in West Java, who answer the right answer when solving the word problem of trigonometry (Arlinwibowo et al., 2021; Rosidin et al., 2019). Therefore, it is important to analyse high school students' errors in solving the word problem of trigonometry.

Error analysis is a method that is used to identify the cause of students' errors when they make consistent mistakes by looking for the pattern of misunderstanding (Lai, 2012). Error analysis is important because it can be a powerful tool to diagnose learning difficulties and consequently direct remediation in mathematics (Borasi, 1987; Hasanah \& Yulianti, 2020). By analysing the errors, teachers can provide instruction targeted to the area of students' needs. Several theories has been found to analyze the error made by students, one of the famous and detail theory is Newman Error Hierarchical Model.

Based on Newman (1977), students' errors involve five levels: 1) reading error, which is the error that students have when they are incomplete in reading the problem; 2) comprehension error, which is the error that students made in understanding and comprehending the problem; 3) transformation error, which is the error that students made when transforming the real problem given in the form of sentence to mathematical form and strategy; 4) process skill error, which is the error that students made in applying the strategy chosen to solve the problem; and 5) encoding error, which is the error that students made when they write the solution incompletely or wrong in giving the final conclusion. This framework is appropriate to be used in analysing students' errors in solving word problems since Newman Error Analysis provided a framework for considering the reasons that underlay the difficulties students experienced with mathematical word problems and a process that is to be determined where misunderstanding occurred (Argaswari, 2016; White, 2010). 
Considering those problems and the urgency that mathematics education community need to improve students' skills in connecting mathematics and real-life context especially in the topics of trigonometry, this research intended to analyse the high school students' error of grade $\mathrm{X}$ in solving word problems of trigonometry based on the Newman Error Hierarchical Model.

\subsection{Research Question}

The research question to be answered by this research is what are errors made by high school students of Grade $\mathrm{X}$ in solving word problems of trigonometry based on the Newman Error Hierarchical Model?

\subsection{Research Objective}

The objective of this research is to identify students' errors in solving word problems of trigonometry according to the Newman Error Hierarchical Model.

\subsection{Significance of Research}

This research has significance for teachers, university, and other researchers. For teachers, this research can be used as a reference to improve and diagnose learning difficulties especially students' error and consequently direct remediation in the process of learning and teaching of mathematics. Moreover, this study can help teachers to design effective practice teaching strategies for the students in learning and solving the word problem of trigonometry. Not only that, this research has an important implication for teachers in developing the test and tasks in the classroom so that the students can improve their understanding and ability in learning trigonometry, especially in the type of trigonometry word problems.

For other researches, this research will enrich the study and investigation of what error that high school students made when solving the word problem of trigonometry. This research can contribute as a reference for other researchers who conduct research in the same area of study.

\section{METHOD}

In order to address the objective of this study, a qualitative descriptive was used as the research method in this study. According to Lambert and Lambert (2012), qualitative descriptive methods provide more in-depth examination and understanding of individual learners through their experiences. Data gathered based on fact, and data analysis presented descriptively. In this case, researcher gather and analyze the error of individual learners made when solving the word problem of trigonometry in depth through their understanding, then present the data result descriptively. Qualitative descriptive gives a comprehensive summarization of specific events experienced by individuals or groups of individuals (Lambert \& Lambert, 2012). Therefore, a qualitative descriptive is appropriate to be used in this study since this study aims to analyze the phenomenon of what errors that students made in solving word problems of trigonometry.

There are several phases that are used in this study as the research procedure. Firstly, the researcher begins with the step of preliminary study. The preliminary study includes identifying the research problem, the research question, the objective or purpose of the study and the literature review. Research problem is the problem or issue that guides the need for conducting a study (Creswell, 2012). Based on the research problem chosen, the researcher 
determines the objective and the research question addressed in the study. The research question of this study is: what are errors made by high school students in solving word problems of trigonometry based on the Newman Error Hierarchical Model?

After identifying the preliminary study, the researcher develops the instruments to be used for collecting the data. The instruments to be used are instrument test and interview form. The instrument test should be validated by validators, while the interview form is not required to be validated since it was adopted from Newman Interview Procedure that has been translated to Bahasa Indonesia which the language that students used. After validating the instrument test, researchers collect the data which are test and personal interview. Before that, researchers determine the population that will be the target of this study, which is 10th grade students of SMAN 1 Cikarang Utara.

In collecting the data, there are phases that the researcher conducts which are conducting the test and conducting the interview. Before conducting the test, researcher make appointments with the school to process the research letter from the university as the permission to conduct this study. After that, researcher interview the teacher about the students and class context in which topics they are going to learn in mathematics. Then, the researcher is allowed to conduct the research in one class. In conducting the test, researcher gives the instrument test to the students that consist of word problems of trigonometry. The test was conducted on March 8th 2021, and conducted through online meeting. After getting the test data, the researcher assesses students' test and categorizes the student's score (low, medium, high) in order to determine the sample to be interviewed. Then, the researcher conducts a personal interview to the sample of six students which are about $20 \%$ of the total students in a class, which are 2 students with lower score, 2 students with medium score, and 2 students with higher score.

The phase of collecting data interviews was conducted on a different day which is not far from the day of the test in order to avoid the unexpected event response of students such as forgetting about the questions, having low motivation to do the interview, etc. Before analyzing the data, researchers need to check whether the data have completed or not. If not complete, the researcher should do the iteration to the first step that is needed. If the data have completed, then the researcher continues to analyze the data. After getting the complete data collection, the researcher analyzes the data based on Newman Error Hierarchical Model. This has be done by calculating the points on which error on the stage of Newman's whether it is on the reading, comprehension, transformation, process skill, or encoding error. Finally, the researcher draws the conclusion and suggestion and presents it to the research paper. The chart flow of research procedure is given in Figure 1. 


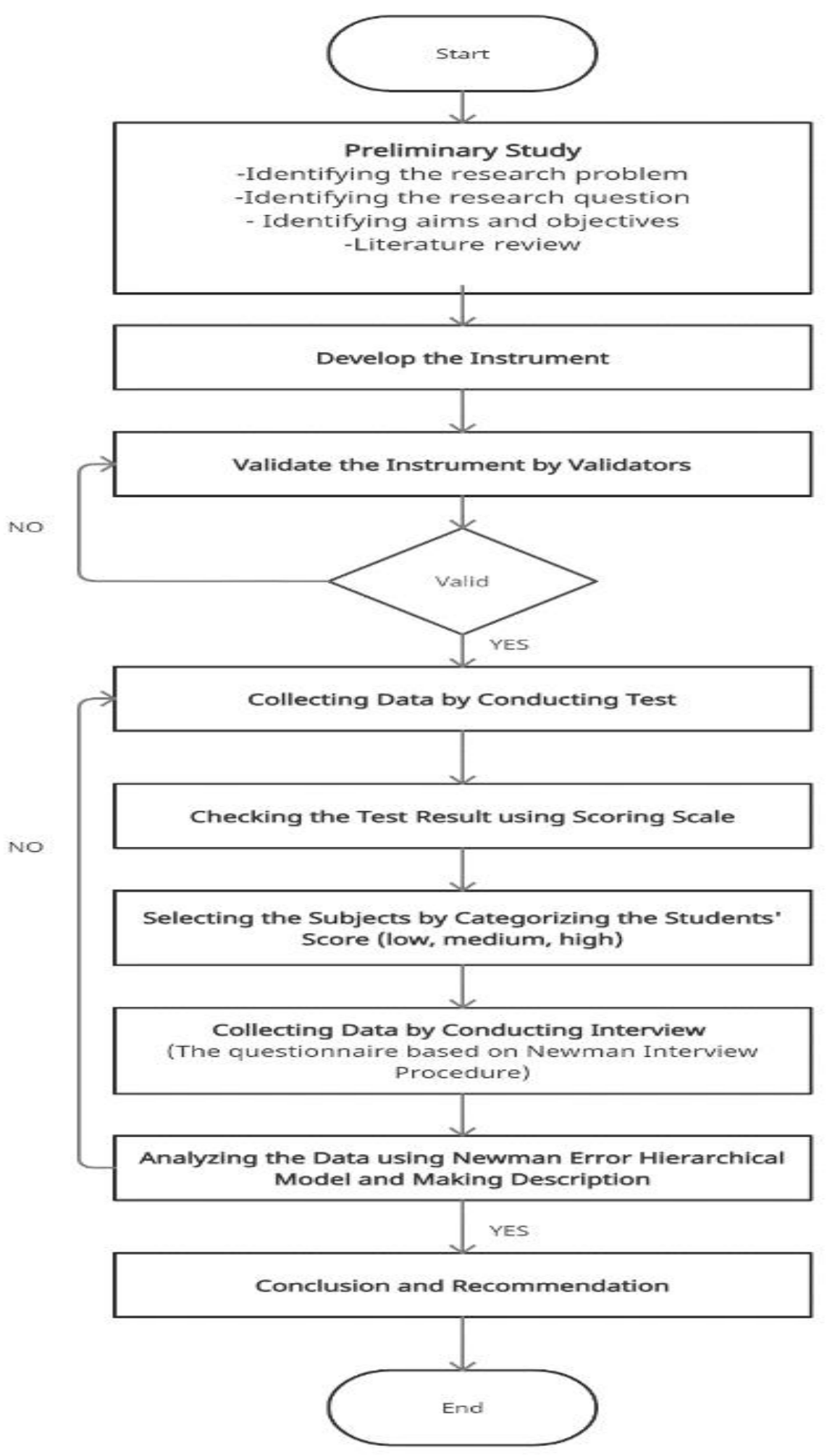

Figure 1. Research procedure 


\subsection{Instrument and Data Collection Technique}

There are two kinds of data that will be used. There are questionnaires in the form of a worksheet about the word problem of trigonometry, and personal interviews that will help researchers to investigate types of students' error deeply. The instrument test contains four questions that are constructed of triangle trigonometry subtopic.

The personal interview aims to identify subject's emotions, feelings, and opinions regarding the particular problem that showed in their worksheets. The main advantage of personal interview is the involvement of direct contact between interviewers and interviewees so that the interviewers are able to get accurate screening, capturing verbal and non-verbal responses. Some certain questions were prepared to guide the interview towards the objective of the research based on Newman (1977).

The instrument test is validated, and the face validity will be applied. Face validity is the extent to which a test is subjectively viewed as covering the concept it purports to measure (Taherdoost, 2016). The worksheet / instrument test has been validated by three validators. The researcher takes validity from the experts who are stakeholder in mathematics and also mathematics teachers in school.

\subsection{Data Analysis}

The analysis of qualitative data used Miles and Huberman method (Miles et al., 2018). This method consists of three stages: 1) data reduction, 2) data presentation, and 3) conclusion. The process of data reduction is based on the data result which includes the aspects that are not related with this research. Stage of data presentation, researcher will present data in the form of words, sentences, and tables. The researchers used a scoring scale adopted from Rohmah and Sutiarso (2018) to see the scores of students working on questions. This scoring scale is done by referring to the results of the five steps in solving the trigonometry problem.

\section{RESULTS AND DISCUSSION}

\subsection{Results}

The Results should include the rationale or design of the experiments as well as the results of the experiments. Results can be presented in figures, tables, and text. The Results should include the rationale or design of the experiments as well as the results of the experiments. Results can be presented in figures, tables, and text.

In order to see the overview students error of the population, the researcher collected the instrument data from 31 students grade $\mathrm{X}$ at SMAN 1 Cikarang Utara. The data instrument results of students' error in solving trigonometry word problems are analysed using Newman Error Hierarchical Model. The summary of the data results is presented as the Table 1.

Table 1. Summary of students' error

\begin{tabular}{lccccccc}
\hline \multirow{2}{*}{ Indicators } & \multicolumn{5}{c}{ Problem } & Total & $(\boldsymbol{\%})$ \\
\cline { 2 - 6 } & $\mathbf{1}$ & $\mathbf{2}$ & $\mathbf{3}$ & $\mathbf{4}$ & & \\
\hline Reading Errors & 0 & 0 & 0 & 0 & 0 & 0 \\
Comprehension Errors & 6 & 22 & 12 & 22 & 62 & 17.77 \\
\hline
\end{tabular}




\begin{tabular}{lccccccc}
\hline \multirow{2}{*}{ Indicators } & \multicolumn{5}{c}{ Problem } & Total & $(\boldsymbol{\%})$ \\
\cline { 2 - 5 } & $\mathbf{1}$ & $\mathbf{2}$ & $\mathbf{3}$ & $\mathbf{4}$ & & \\
\hline Transformation Error & 8 & 25 & 15 & 31 & 79 & 22.63 \\
Process Skill Errors & 18 & 25 & 30 & 31 & 104 & 29.8 \\
Encoding Errors & 18 & 25 & 30 & 31 & 104 & 29.8 \\
\hline \multicolumn{1}{c}{ Total } & 50 & 97 & 87 & 115 & 349 & 100 \\
\hline
\end{tabular}

Table 1 shows a summary of the data results of students' errors in solving word problems of trigonometry. Based on the Newman Error Hierarchical Model, there are five types of errors which are reading error, comprehension error, transformation error, process skill error, and encoding error. The percentage column shows the percentage of errors frequency for each type of error made, from the total number errors made by students. Based on the data, there are found $0 \%$ in the reading error, $17.77 \%$ in the comprehension error, $22.63 \%$ in the transformation error, $29.8 \%$ in the process skill error, and $29.8 \%$ in the encoding error out of all students' error. After that, six students from each level of low, medium and high are chosen and interviewed deeply to identify the students' errors.

The six students are the sample to be interviewed, and it has been discovered that there are some errors types students made in solving the word problem of trigonometry. Since the Newman Error Hierarchical Model classified errors based on the level of hierarchy, so the initial error made might cause the subsequent errors in the next level of errors. The coding result of error types that the subjects have in each problem can be seen on the Table 2 .

Table 2. Matrix code of initial students' error

\begin{tabular}{|c|c|c|c|c|}
\hline \multirow{3}{*}{ Subject } & \multirow{2}{*}{ Sine } & \multirow{2}{*}{ Cosine } & \multicolumn{2}{|c|}{ Tangent } \\
\hline & & & Elevation & Depression \\
\hline & 1 & 2 & 3 & 4 \\
\hline A7 & $\begin{array}{c}\text { Transformation } \\
\text { Error }\end{array}$ & $\begin{array}{c}\text { Transformation } \\
\text { Error }\end{array}$ & $\begin{array}{l}\text { Comprehension } \\
\text { Error }\end{array}$ & $\begin{array}{c}\text { Comprehension } \\
\text { Error }\end{array}$ \\
\hline A21 & $\begin{array}{c}\text { Transformation } \\
\text { Error }\end{array}$ & $\begin{array}{c}\text { Transformation } \\
\text { Error }\end{array}$ & $\begin{array}{l}\text { Comprehension } \\
\text { Error }\end{array}$ & $\begin{array}{l}\text { Comprehension } \\
\text { Error }\end{array}$ \\
\hline B4 & $\begin{array}{c}\text { Transformation } \\
\text { Error }\end{array}$ & - & $\begin{array}{l}\text { Comprehension } \\
\text { Error }\end{array}$ & $\begin{array}{c}\text { Comprehension } \\
\text { Error }\end{array}$ \\
\hline B3 & - & $\begin{array}{c}\text { Comprehension } \\
\text { Error }\end{array}$ & Process skill Error & $\begin{array}{c}\text { Comprehension } \\
\text { Error }\end{array}$ \\
\hline C30 & - & - & Process skill Error & $\begin{array}{l}\text { Comprehension } \\
\text { Error }\end{array}$ \\
\hline $\mathrm{C} 23$ & - & - & Process skill Error & $\begin{array}{c}\text { Comprehension } \\
\text { Error }\end{array}$ \\
\hline
\end{tabular}




\subsubsection{Comprehension Error}

All the samples experienced the comprehension error. The error happened when students worked on problems 2, 3, and 4. Students who have errors in comprehension are mostly caused by their lack of understanding and comprehending some words on the problem. Student A7 has an error in comprehending the problem. She writes the information given about what is known incompletely. She did not write and understand the angle of elevation which is the essential information component in the word problem. Not only that, she also did not comprehend the word "from the same ground height" which is the set-up component of the word problem. The set-up component gives the condition of the problem situation. It gives the setting of the problem condition that the angle between the building and ground is 90 degrees (see Figure 2). Therefore, it caused her not to use the right triangle in solving this problem as shown in the picture. She also did not write the question asked. Because of that, she was also wrong in transforming the mathematical model. She drew the angle wrongly.

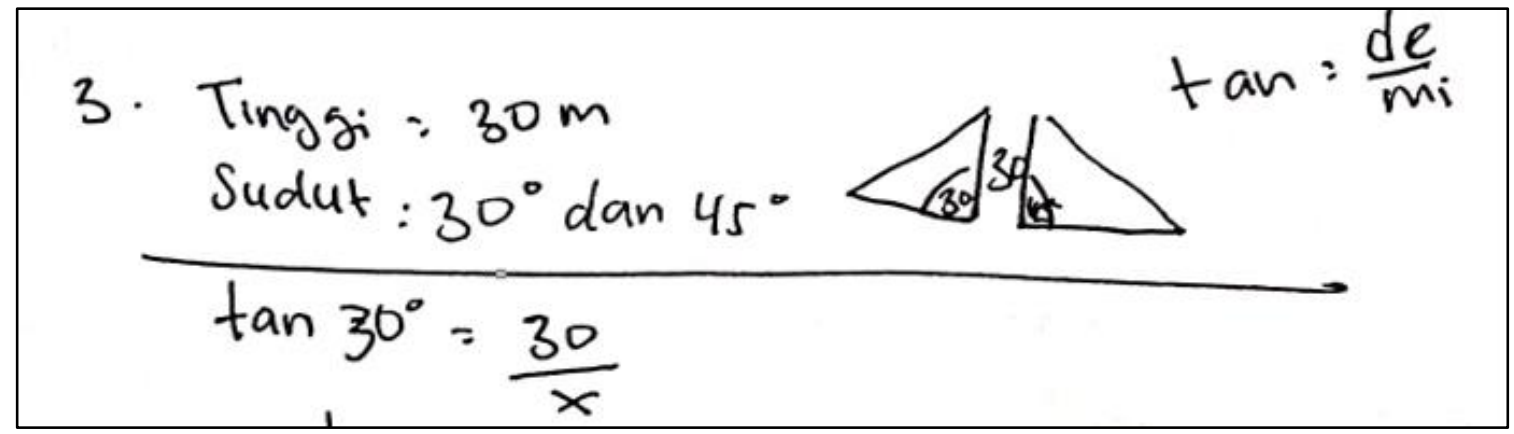

Figure 2. Students' comprehension error on problem 3

Moreover, she did not understand the concept of trigonometry ratio in the right triangle. She said in the interview that the ratio of tangent is opposite over the hypotenuse. She also cannot decide the part of opposite and hypotenuse. Based on her understanding, she assumes that the hypotenuse is adjacent. This error causes the error on the process skill and gives the wrong answer.

Student A21 has an error in comprehending the problem. In the written task, she writes the information given of what is known incompletely. She only wrote that the angles formed are 30 degrees and 60 degrees without any detailed explanation about what type of angles are given. She also did not understand the meaning of the angle of depression. It is shown in the written task that she drew the angle formed between the vessel's view to tower and the horizontal line below the vessel (see Figure 3). In the interview, it is shown that her understanding about the angle of depression was wrong. Other sample students also experience the same typical error details.

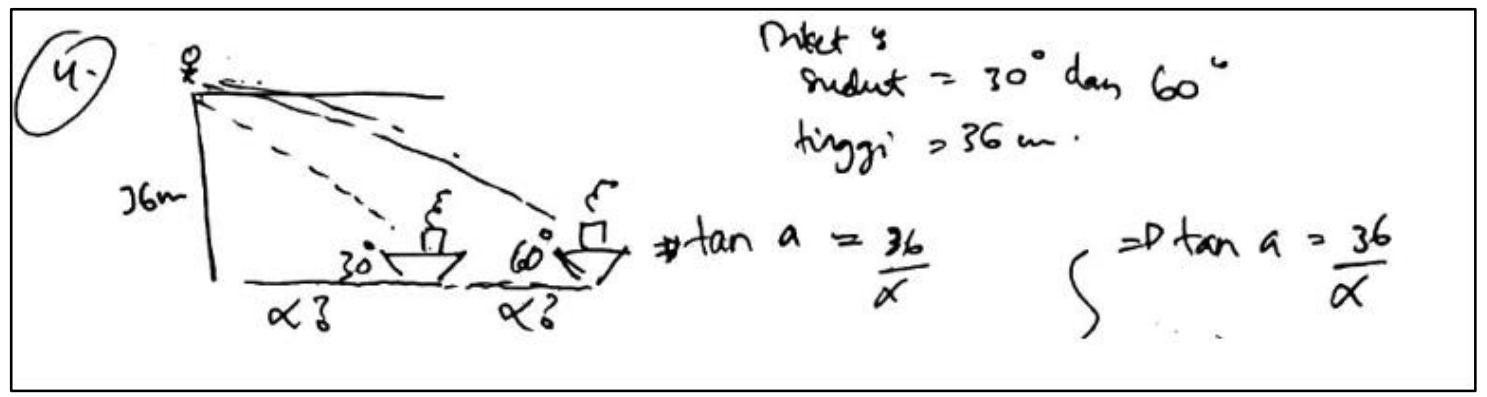

Figure 3. Students' work on problem 4 


\subsubsection{Transformation Error}

It is found that the common transformation error is transforming the word problem into the visual mathematical representation. Students with lower scores have errors in determining the position of length of the kite's string, the position of the objects given, and the appropriate angle position in the mathematical model. Not only that, some of them were also wrong in determining the strategy used in solving the problem. Moreover, they were still confused about the position of SOHCAHTOA, in which part the adjacent, opposite, and hypotenuse lead on the right triangle. It refers to the concept of triangle trigonometry. For students with medium scores, they made errors in positioning the length into the visual mathematics model. Even though they know the information component given and interview, they have difficulties in transforming it. For the students with higher scores, they have errors in transformation but not as the initial error.

Student A21 has an error in transforming the problem into a mathematical model. In the written task and the interview, she knows that the given information is the length of the kite's string is $120 \mathrm{~m}$, the angle formed is 60 degrees, and the asked question is to find the distance between the ground and the kite. However, she cannot transform the kite's string into the model well. She assumes that the length is always transformed as the horizontal line. She said in the interview that the concept is similar to the concept of a rectangle in which the length of the rectangle is located as the horizontal line, while the width of the rectangle is located as the vertical line. It is not true that the length is always the horizontal line. Therefore, she has errors in transforming the mathematical model. As a consequence, she was wrong in deciding the strategy plan to solve the problem. She uses tangent instead of using the ratio of sine (see Figure 4). She also was wrong in the process skill and the encoding in solving the problem. Therefore, she has errors in transformation, comprehension, process skill, and encoding.

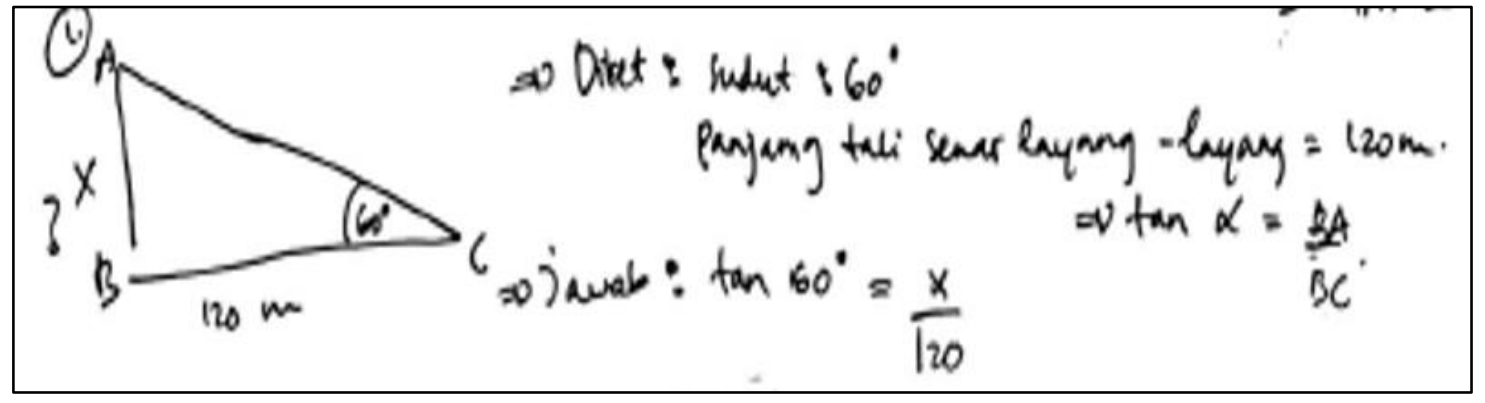

Figure 4. Students' work on problem 1

\subsubsection{Proces Skill Error}

Students who have errors in process skill commonly are caused by their lack of calculation and doing the algebra. Some students were wrong in finding the variable of asked questions in the algebra concept. Not only that, some of them are also wrong in deciding the value of the trigonometry ratio.

Student B3 has errors in the process skill. After succeeding in reading, comprehension, and transformation; she failed to obtain the right ratio value of $\cos 30$ degrees. In the written task, she writes $\cos 30^{\circ}=\frac{\sqrt{2}}{2}$. The right ratio for $\cos 30^{\circ}$ should be $\frac{\sqrt{3}}{2}$ (see Figure 5). Because of that, the researcher interviewed the student to investigate this error. Based on the written instrument task and the interview, the student was wrong in obtaining the ratio number of $\cos 30^{\circ}$. It is because she forgot the value of trigonometry ratio even though the value of trigonometry ratio table was provided in the instrument. As a result, 
she was also wrong in giving the final solution. Therefore, student B3 has errors in the process skill and encoding.

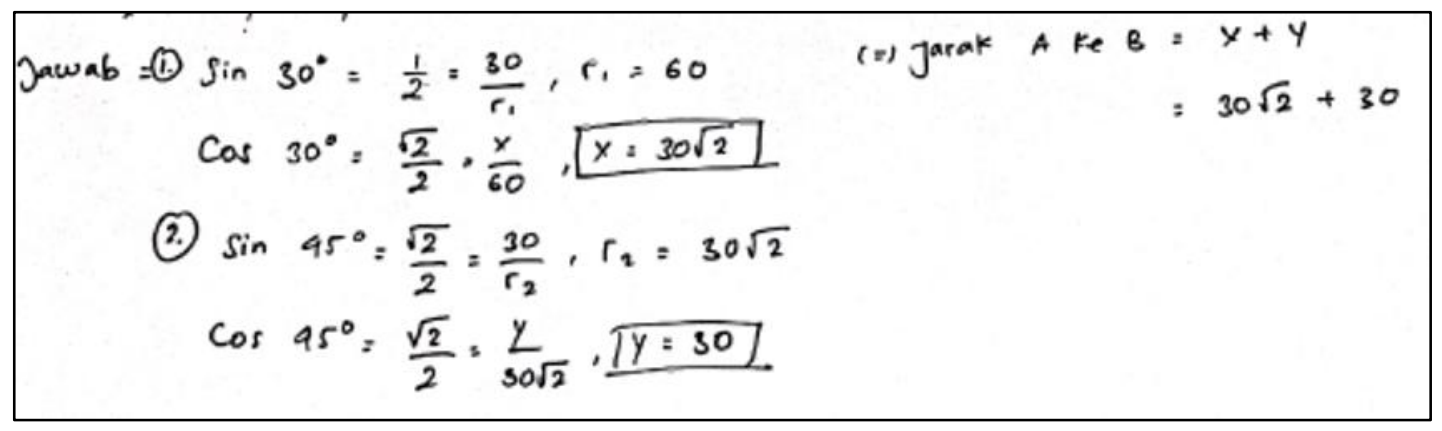

Figure 5. Students' work on problem 3

\subsubsection{Encoding Error}

As can be seen from Table 2, students made error in encoding not as the initial error, but as the consequence of the previous errors. It happens on subjects who has error in the previous stage of errors. It is found that mostly students did not write and make the conclusion for the problem solution. It is because they confused about the final solution since problem number 3 and 4 require multi-steps to be solved. As the consequence, students cannot decide the final solution, then cause the low motivation to finish the solution.

\subsection{Discussion}

The results show that the students made some errors in solving the word problem of trigonometry. The data result follows the Newman Error Hierarchical Model to analyse the errors. It shows that if students make errors in the first stage, the following stages will result in further errors. Based on the results, students of SMAN 1 Cikarang Utara have errors in comprehending the problem, transforming the problem into mathematical models and strategy, processing the operations, and encoding the solution when solving the word problem of trigonometry. Students have no reading errors in solving the problem. This finding is in line with the previous study of Usman and Hussaini (2017) and Fatmanissa and Sagara (2017) that high school students have no error in reading the problem. Both studies show there were no reading errors found since high school students have good reading skills. The students were able to read the information and mathematical symbols completely.

Although the students were able to read the problem, they have errors in comprehending the mathematics word problem. It means that although they can read the problem completely, but they cannot understand the meaning of some words in the problem. All the six subject samples made initial errors in comprehending the problem. Most of them made errors in comprehending the angle of depression. It is because students are not familiar with those words in daily real life. They did not understand, for the students with low and medium scores, and have misunderstanding, for students with high scores, about the definition of depression angle so that it caused the error. Another error made by students with lower scores is they cannot interpret the key word in the information component of simple terms. According to Sumule et al. (2018), students have this error because they cannot understand and interpret key words in the problem. While for students with medium score, students do not read the questions carefully so that there is unreadable information that leads them to carelessness. It can be concluded that students made error in comprehending the set up and information component, which is not explained in the previous research (Dewanto et al., 2017) which is only explained that students have comprehension error because the 
problem is too long without any explanation in which problem component that students made the error.

Another error found in this research is the transformation error, where students were not able to transform the mathematical word problem into mathematical representation. It is found in student A7 where she was wrong in transforming and imagining the visual representation. It occurred because there is a difficulty of the students in recognizing and imagining the context in which a word problem is set, or their approach is altered by the context in which the word problem is given (Gooding, 2009). Not only that, there are students who have errors in transforming the mathematical word problem into mathematical strategy. They were wrong in determining the appropriate strategy in order to solve the problem. It is in line with Nanmumpuni and Retnawati (2021), that students were confused in choosing the right concepts of trigonometry to solve the problems. They were confused in deciding the trigonometry ratio that might be the strategy to solve the problem. It is because students have a lack of understanding the triangle trigonometry concept. They were confused in deciding which one is the opposite, adjacent, and hypotenuse. It is in line with the previous study that there are still many students who incorrect to determine ratio trigonometry (Erlisa \& Prabawanto, 2019).

Process skill error is the error that students make when they are not able to process the procedural and the computation in carrying out the problem after deciding the mathematical strategy. Students who have errors in process skill commonly are caused by their lack of calculation and doing the algebra. Some students were wrong in finding the variable of asked questions in the algebra concept. It occurred because students have a lack of ability in doing algebra, while algebra takes an important role to be connected in trigonometry (Demir \& Heck, 2013; Hidayat \& Aripin, 2020). For the calculation error, students were wrong in determining the value of trigonometry ratio and calculating the operation. It is caused by the carelessness and lack of focus resulting in less precision (Hidayat \& Riyana, 2021; Kelly \& Mousley, 2001).

In the encoding stage, there are some students who did not write and make the conclusion for the problem solution. For example, student A7 made encoding errors in a problem that required multi-steps in attempting the solution. She was confused about the final solution so that she did not find the distance between two objects. This is related to (Dewanto et al., 2017) that problems requiring multi-steps will tend students to make errors. The fact that it can be solved by adding the result of the previous work that she has solved if she writes and comprehends what is asked.

\section{CONCLUSION}

The objective of this research is to identify students' error in solving word problems of trigonometry according to Newman Error Hierarchical Model. The population of this research are 31 students of grade X IPA 2 SMAN 1 Cikarang Utara, and the sample are six students of grade X IPA 2. Based on the instrument test results and interviews, it can be concluded that high school students made errors in solving word problem of trigonometry which are: 1) The percentage of errors in comprehension stage is $17.77 \%$ where students made error in comprehending and understanding the problem; 2) The percentage of errors in transformation stage is $22.63 \%$ where students made error in transforming the real problem given in the form of sentence to mathematical form and strategy; 3) The percentage of errors in process skill stage is $29.8 \%$ where students made errors in applying the strategy chosen to solve the problem especially in doing the algebra and calculation; 4) The percentage of 
errors in encoding stage is $29.8 \%$ where students made error when they write the solution incompletely or wrong in giving the final conclusion.

Students who have errors in comprehension are mostly caused by their lack of understanding and comprehending some words and terms on the word problem. Mostly they have errors in comprehending the set up and the given information component which led them to make errors in comprehending the situation and essential information of the problem given. Then, students who have errors in transformation are caused by lack of ability in transforming the word problem to the mathematical model and strategy. Moreover, they are wrong in determining the strategy used in solving the problem. It is because they were still confused about the position of SOHCAHTOA, in which part the adjacent, opposite, and hypotenuse lead on the right triangle. It refers to the concept of triangle trigonometry. While, students who have errors in process skill commonly are caused by their lack of processing the algebra and calculation. Some students were wrong in finding the variable of asked questions in the algebra concept. Not only that, some of them are also wrong in deciding the value of the trigonometry ratio. Meanwhile, students who have errors in encoding are mostly caused by their lack of motivation in deciding and finishing the final solution. Some students are also made error caused by carelessness.

\section{ACKNOWLEDGEMENTS}

We would like to express our gratitude and thanks to all lecturers in the Mathematics Education Department, Faculty of Education, Sampoerna University for the help and support during the project. We also thank the students and teachers at Grade X SMAN 01 Cikarang Utara, especially Ibu Nurita as the mathematics teacher who helped and allowed us in conducting the research. Lastly, we would like to thank Ibu Ani, mathematics teacher SMAN 01 Cikarang Utara, and Ibu Namirah Fatmanissa, mathematics lecturer Sampoerna University, who helped us in validating the research instruments.

\section{REFERENCES}

Argaswari, D. P. A. D. (2016). Pengembangan modul pembelajaran berdasarkan teori van hiele pada pokok bahasan segiempat untuk meningkatkan level berpikir geometri siswa kelas VII smpn 1 Selogiri. Thesis. UNS (Sebelas Maret University).

Arhin, J., \& Hokor, E. (2021). Analysis of High School Students' Errors in Solving Trigonometry Problems. Journal of Mathematics and Science Teacher, 1(1), em003. https://doi.org/10.29333/mathsciteacher/11076

Arlinwibowo, J., Achyani, I., \& Kurniadi, G. (2021). Multidimentional item respose utilization for validating mathematics national examination in Indonesia. Journal of Physics: Conference Series, 1764(1), 012113. https://doi.org/10.1088/17426596/1764/1/012113

Boonen, A. J. H., de Koning, B. B., Jolles, J., \& van der Schoot, M. (2016). Word Problem Solving in Contemporary Math Education: A Plea for Reading Comprehension Skills Training [Original Research]. Frontiers in psychology, 7, 191. https://doi.org/10.3389/fpsyg.2016.00191

Borasi, R. (1987). Exploring Mathematics through the Analysis of Errors. For the learning of Mathematics, 7(3), 2-8. Retrieved from http://www.jstor.org/stable/40247900 
Creswell, J. W. (2012). Educational research: Planning, conducting, and evaluating quantitative and qualitative research (4th ed.). Pearson.

Cuevas, G. J. (2000). The Problem-Solving Process of Research on Word Problems [Word Problems: Research and Curriculum Reform, Stephen K. Reed]. The American Journal of Psychology, 113(2), 322-325. https://doi.org/10.2307/1423735

Demir, Ö., \& Heck, A. (2013). A new learning trajectory for trigonometric functions. In Proceedings of the 11th international conference on technology in mathematics teaching.

Dewanto, M. D., Budiyono, B., \& Pratiwi, H. (2017). Students' error analysis in solving the math word problems of high order thinking skills (HOTS) type on trigonometry application. In 1st Annual International Conference on Mathematics, Science, and Education (ICoMSE 2017). https://doi.org/10.2991/icomse-17.2018.34

Erlisa, W., \& Prabawanto, S. (2019). Identification of Learning obstacle in trigonometry materials In senior high school. In International Seminar STEMEIF (Science, Technology, Engineering and Mathematics Learning International Forum).

Fatmanissa, N., Kusnandi, K., \& Usdiyana, D. (2020). Effect of Schema Use in Solving Word Problems: Emphasis on Linguistic Difficulties. Contemporary Mathematics and Science Education, 1(2), ep20006. https://doi.org/10.30935/conmaths/8495

Fatmanissa, N., \& Sagara, R. (2017). Language literacy and mathematics competence effect toward word problems solving [word problem; basic Mathematics competence; $\begin{array}{llll}\text { language literacy]. } & \text { Infinity, }\end{array}$ https://doi.org/10.22460/infinity.v6i2.p195-206

Franklin, J. (2006). Divine proportions: Rational trigonometry to universal geometry. The Mathematical Intelligencer, 28(3), 73-74. https://doi.org/10.1007/BF02986892

Galarza, M. L. O. (2017). The Influence of Multiple Representations on Secondary Students' Understanding of Trigononetric Functions. Dissertation. University of Texas at El Paso.

Gooding, S. (2009). Children's difficulties with mathematical word problems. In Proceedings of the British Society for Research into Learning Mathematics. Retrieved from https://bsrlm.org.uk/wp-content/uploads/2016/02/BSRLM-IP-29-306.pdf

Gur, H. (2009). Trigonometry Learning. New Horizons in Education, 57(1), 67-80. Retrieved from https://files.eric.ed.gov/fulltext/EJ860819.pdf

Hamzah, N., Maat, S. M., \& Ikhsan, Z. (2021). A systematic review on pupils' misconceptions and errors in trigonometry. Pegem Journal of Education and Instruction, 11(4), 209-218. https://doi.org/10.47750/pegegog.11.04.20

Haryanti, M. D., Herman, T., \& Prabawanto, S. (2019). Analysis of students' error in solving mathematical word problems in geometry. Journal of Physics: Conference Series, 1157(4), 042084. https://doi.org/10.1088/1742-6596/1157/4/042084

Hasanah, A. N., \& Yulianti, K. (2020). Error analysis in solving prism and pyramid problems. Journal of Physics: Conference Series, 1521(3), 032035. https://doi.org/10.1088/1742-6596/1521/3/032035

Hidayat, W., \& Aripin, U. (2020). Identifikasi kesalahan jawaban mahasiswa pada mata kuliah trigonometri berdasarkan dimensi pengetahuan Krathwohl [Identification of 
student answer errors in trigonometry courses based on the Krathwohl knowledge dimensions]. JNPM (Jurnal Nasional Pendidikan Matematika), 4(1), 142-153. https://doi.org/10.33603/jnpm.v4i1.3316

Hidayat, W., \& Riyana, E. (2021). Desain lintasan belajar trigonometri materi aturan sinus dengan strategi relating, experiencing, applying, cooperating, transferring (REACT) [Trigonometry learning trajectory design for sine rule material with strategies relating, experiencing, applying, cooperating, transferring (REACT)]. JNPM (Jurnal Nasional Pendidikan Matematika), 5(2), 296-309.

Kelly, R. R., \& Mousley, K. (2001). Solving Word Problems: More Than Reading Issues for Deaf Students. American Annals of the Deaf, 146(3), 251-262. Retrieved from http://www.jstor.org/stable/44393481

Khoshaim, H. B. (2020). Mathematics Teaching Using Word-Problems: Is It a Phobia! International Journal of Instruction, 13(1), 855-868. https://doi.org/10.29333/iji.2020.13155a

Lai, C.-F. (2012). Error Analysis in Mathematics. Technical Report\# 1012. Behavioral Research and Teaching. Retrieved from https://files.eric.ed.gov/fulltext/ED572252.pdf

Lambert, V. A., \& Lambert, C. E. (2012). Qualitative descriptive research: An acceptable design. Pacific Rim International Journal of Nursing Research, 16(4), 255-256.

Mensah, F. S. (2017). Ghanaian senior high school students' error in learning of trigonometry. International Journal Of Environmental \& Science Education, 12(8), 1709-1717.

Miles, M. B., Huberman, A. M., \& Saldaña, J. (2018). Qualitative data analysis: A methods sourcebook. Sage publications.

Nanmumpuni, H. P., \& Retnawati, H. (2021). Analysis of Senior High School Student's Difficulty in Resolving Trigonometry Conceptual Problems. Journal of Physics: Conference Series, 1776(1), 012012. https://doi.org/10.1088/1742$6596 / 1776 / 1 / 012012$

Newman, M. A. (1977). An Analysis of Sixth-Grade Pupil's Error on Written Mathematical Tasks. Victorian Institute for Educational Research Bulletin, 39, 31-43. Retrieved from https://ci.nii.ac.jp/naid/20000706650/en/

Rohmah, M., \& Sutiarso, S. (2018). Analysis problem solving in mathematical using theory Newman. Eurasia Journal of Mathematics, Science and Technology Education, 14(2), 671-681. https://doi.org/10.12973/ejmste/80630

Rosidin, U., Herpratiwi, H., Suana, W., \& Firdaos, R. (2019). Evaluation of national examination (UN) and national-based school examination (USBN) in Indonesia. European Journal of Educational Research, 8(3), 827-937. https://doi.org/10.12973/eu-jer.8.3.827

Said, S. N., \& Tengah, K. A. (2021). Supporting solving word problems involving ratio through the bar model. Infinity, 10(1), 149-160. https://doi.org/10.22460/infinity.v10i1.p149-160

Sanwidi, A. (2018). Students' representation in solving word problem. Infinity, 7(2), 147 154. https://doi.org/10.22460/infinity.v7i2.p147-154 
Sumule, U., Amin, S. M., \& Fuad, Y. (2018). Error analysis of Indonesian junior high school student in solving space and shape content PISA problem using Newman procedure. Journal of Physics: Conference Series, 947, 012053. https://doi.org/10.1088/17426596/947/1/012053

Taherdoost, H. (2016). Validity and reliability of the research instrument; how to test the validation of a questionnaire/survey in a Research. International Journal of Academic Research in Management (IJARM), 5(3), 28-36. https://doi.org/10.2139/ssrn.3205040

Usman, M. H., \& Hussaini, M. M. (2017). Analysis of students' error in learning of trigonometry among senior secondary school students in Zaria Metropolis, Nigeria. IOSR Journal of Mathematics, 13(2), 1-4. https://doi.org/10.9790/5728-1302040104

Walsh, R., Fitzmaurice, O., \& O’Donoghue, J. (2017). What Subject Matter Knowledge do second-level teachers need to know to teach trigonometry? An exploration and case study. Irish Educational Studies, 36(3), 273-306. https://doi.org/10.1080/03323315.2017.1327361

White, A. L. (2010). Numeracy, Literacy and Newman's Error Analysis. Journal of Science and Mathematics Education in Southeast Asia, 33(2), 129-148. 
